\title{
KİŞI-ÖRGÜT UYUMUNUN GÖREV VE BAĞLAMSAL PERFORMANS İLE ILIŞKISII: İŞ TUTUMLARININ ARACILIK ROLÜ
}

\author{
Eda ÇAM (1) \\ Gebze Teknik Üniversitesi, İşletme Fakültesi, Kocaeli (edaa_okms@hotmail.com) \\ Doç. Dr. Meral ELÇI ID \\ Gebze Teknik Üniversitesi, İşletme Fakültesi, Kocaeli (emeral@gtu.edu.tr) \\ Dr. Öğr. Üyesi Büşra MÜCELDILİ \\ Yıldız Teknik Üniversitesi, İ̈BF, İstanbul (busramu@yildiz.edu.tr)
}

\begin{abstract}
ÖZET
Bu çalışmanın amacı, kişi-örgüt uyumu ile görev ve bağlamsal performans arasındaki ilişkide iş tutumlarının (örgütsel bağlllık ve iş tatmini) aract rollerinin incelenmesidir. Bu ilişkilerin analiz edilmesinde, Marmara Bölgesi'nde kamu ve özel sektör işletmelerinde çalışan 331 katılltmcıdan anket tekniği ile veri toplanmıştır. Araştırma modeli yapısal eşitlik modeli kullanılarak analiz edilmiştir. İlk olarak doğrulayıcı faktör analizi ardından kavramsal model kapsamındaki iliş̧ileri test etmek amacıyla yol analizi yapılmıştır. Yapılan analizler sonunda elde edilen temel bulgular şu şekildedir; kişi-örgüt иуити görev ve bağlamsal performans ile pozitif bir ilişkiye sahiptir. Ayrıca iş tutumları, bu ilişkide aracı rol oynamaktadir.
\end{abstract}

Anahtar Kelimeler: Kişi-Örgüt Uyumu, İş Tutumları, Örgütsel Bağlılık, İş Tatmini, Görev Performansı.

\section{THE RELATIONSHIP AMONG PERSON ORGANIZATION FIT AND TASK AND CONTEXTUAL PERFORMANCE: THE MEDIATING ROLE OF JOB ATTITUDES}

\begin{abstract}
This paper aim is to examine the mediator roles of job attitudes (organizational commitment and job satisfaction) on person-organization fit, task and contextual performance relationship. In the analysis of these relationships, data were collected by survey method from 331 employees working in public and private sector enterprises in Marmara Region. The research model was analyzed using structural equation modelling. The main findings obtained from the analyzes are as follows; person-organization fit has a positive relationship with the task and contextual performance. In addition, work attitudes have a mediating role in this relationship.
\end{abstract}

Keywords: Person-Organization Fit, Job Attitudes, Organizational Commitment, Job Satisfaction, Task Performance. 


\section{Giriş}

Uluslararası rekabetin şiddetli bir şekilde yaşandığı ve pazar paylarının yerel rakiplerin yanı sıra ulusal ve küresel rakipler tarafından da tehdit edildiği günümüz işletmeleri için öncelikli olan, örgüt içindeki süreçlerin işleyişinde yaşanan sorunların çözüme kavuşturulmasının ardından pazardaki fırsat ve tehditlerin değerlendirilmesidir. Bu noktada yoğun rekabet ortamında faaliyet gösteren işletmeler çalışanları üzerine daha fazla sorumluluklar yükleyebilmekte ve yüksek sorumlulukların üstesinden gelemeyen çalışanlar ise iş süreçlerinin işleyişine zarar verebilmektedirler. Uyum ve güven sorunlarının olduğu, yüksek çatışma ve stres düzeyinin yaşandığı işletmeler ise günümüz rekabet ortamına daha fazla dayanamamaktadırlar.

Örgüt ve çalışanlar arasında var olan sorunların çözülebilmesi için kişi-örgüt uyumu sürecinin gerçekleşebilmesi gerekmektedir (Moripek, 2016:6). Kişi-örgüt uyumu; örgüt ve bireyin uzun yıllar beraber olma ortak niyetini oluşturan faktörlerin tamamının ya da büyük bir kısmının her iki tarafta da bulunması ve bu faktörlerin birbirleriyle örtüşmesi olarak tanımlanabilmektedir. $\mathrm{Bu}$ örtüşme neticesinde, ne çalışan örgütünü terk etmeyi ne de örgüt çalışanından vazgeçmeyi düşünmemektedir. Diğer taraftan, örgüt ve kişi arasındaki bu uyumun başlangıçta etkin işe alma ve sonrasında planlı uyumlaştırma faaliyetleri neticesinde gerçekleştirilebileceği gibi, yönetici ve liderlerin örgüt kültüründe yapabildikleri küçük değişikliklerle de sonradan sağlanabilmektedir (Adıgüzel \& Kayadibi, 2015). Kişi örgüt uyumunun sağlanması kurumlara pozitif katkılar sağlamaktadır. Örgütsel davranış literatürü incelendiğinde kişi örgüt uyumunun sübjektif ve objektif performans üzerinde dolaylı ve direkt etkileri olduğu görülmektedir. (McCulloch \& Turban, 2007; Arthur vd., 2006).

$\mathrm{Bu}$ çalışmanın amacı kişi örgüt uyumu ile görev ve bağlamsal performans arasındaki ilişkileri belirlemek ek olarak iş tutumlarından iş tatmini ve örgütsel bağlılık arasındaki ilişkileri incelemektir. Çalışmada kişi örgüt uyumunun hem dolaylı hem de direkt ilişkileri kavramsal olarak tartışılacak ardından ampirik olarak test edilecektir.

\section{Literatür Taraması}

\subsection{Kişi Örgüt Uyumu}

Kişi-örgüt uyumu ile ilgili literatürde çeşitli kuramsal yaklaşımlar geliştirilmiştir. Bunlardan ilki Kristof (1996) tarafından geliştirilen yaklaşımdır. Kristof kişi-örgüt uyumunu, çalışan ile örgüt arasında işlevselleştirilmiş uyum olarak ele almış ve bu çerçeveden hareketle kişi-örgüt uyumunu, birey ile örgüt arasındaki beklentilerin ve değerlerin uyum sağlaması olarak tanımlamıştır. Bu noktada çalışan ile örgütün karşılıklı beklentilerini ne şekilde karşılayacaklarını birbirlerine açıklamaları önemlidir (Elden, 2017). Örgütler; çalışanların görevleri ile ilgili ihtiyaç duydukları fiziksel kaynakların yanı sıra, finansal ve psikolojik kaynakları da onlara sağlar. Buna karşılık, örgütler çalışanlarından bağlılık, zaman, çaba, bilgi, yetenek ve becerileri doğrultusunda katkı talep ederler (Akbaş, 2010). Dolayısıyla Kristof'a göre kişi-örgüt uyumu için önemli olan, örgütün sağladığı kaynaklar ile çalışanından talep ettiği ve çalışanın örgüte sunduğu katkı arasında uyumun sağlanmasıdır.

İkinci yaklaşım Chatman (1989)'nin kişi-örgüt uyumu yaklaşımıdır. Chatman kişi-örgüt uyumu yaklaşımında değerler yönüne vurgu yapmaktadır (Elden, 2017). Chatman (1989)'e göre işletme bünyesindeki çalışanların sahip olduğu değerler, gerek işe alım sürecinde uygulanan 
politikalar gerekse de daha sonrasında örgüt içerisinde yürütülen uygulamalar neticesinde, örgütün sahip olduğu değerlerle zaman içerisinde benzeşmekte, dolayısıyla örgütün değerleri, çalışanların çoğunluğunun değerleri ile benzer olmaktadır.

Kişi-örgüt uyumu ile ilgili literatürde geliştirilen diğer bir yaklaşım ise Schneider (1987)'e aittir. Schneider'in (1987) kişi-örgüt uyumu modeli, Çekim-Seçim-Sürtüşme (Attraction-Selection-Attrition) olarak isimlendirilmektedir. Burada çekim, kişilerin kendilerine en uygun işi bulduklarını ifade etmektedir. Seçim, bireylerin işletme seçiminde örgütün parçası olma isteğinin önemli olduğunu ve işin parçası olarak seçilen bireyin ise üstlendiği görevleri yerine getirerek örgüt içi konumunun belirlendiğini ifade etmektedir. Son olarak sürtüşme ise kişilerin örgütle yüksek seviyede uyumlarının olması gerekliliğini, aksi takdirde işten ayrılmanın (sürtüşme) yaşanacağını ifade etmektedir (Elden, 2017).

\section{2. İş Tutumları}

Bireyler hayatları boyunca karşılaştıkları nesne, kişi ve olaylara karşı nasıl tutumlar geliştirmektedirler. Örgütsel davranış literatürü ise bireyin dış çevresi ile ilgili geliştirdiği tutumlardan ziyade işine karşı geliştirdiği tutumlara vurgu yapmaktadır (Budak, 2006:91). Bu tutumlar bireylerin yaptıkları iş ve çalıştıkları örgüt ile ilgili olarak geliştirdikleri olumlu ya da olumsuz değerlendirmeleri içerir (Robbins \& Judge, 2013)

Örgütsel davranış alanında başlıca iş tutumları arasında iş tatmini, işe sarılma, örgütsel bağlılık, örgütsel destek algısı ve çalışanın işe angaje olması (tutulması) incelenmektedir. $\mathrm{Bu}$ çalışmada temel iş tutumları olarak iş tatmini ve örgütsel bağlılık esas alınmıştır. Çünkü bu iki tutum türü özellikle işyerinde, nasıl davranıldığı üzerinde en fazla etki potansiyeline sahip olan iki iş tutumudur (Carpenter vd., 2010). Bu sebepten dolayı, örgütsel bağlılık ve iş tatmini, çalışma ortamı içerisinde en çok incelenen ve tartışılan tutumlardan ikisini temsil etmektedir (Hill \& McShane, 2008:357).

İş tatmini, işin özelliklerinin değerlendirilmesi sonucu oluşan ve iş hakkındaki olumlu duyguyu açılayan bir olgudur (Robbins \& Judge, 2013:77). İş tatmininin örgütsel davranış alanında derinlemesine araştırılan kavramlardan biri olmasının genel olarak iki sebebi vardır. İlki, iş tatmininin genel olarak sorumluluk, görev çeşitliliği ya da iletişim gereksinimleri gibi çalışma koşullarından güçlü bir şekilde etkilenen bir olgu olmasından dolayı herkesin ilgisini çekmiştir. Ayrıca iş tatminsizliği, devamsızlık, istikrarsızlık, verimsizlik, zarar verici davranışlar veya sabotaj gibi istenmeyen davranışlara neden olmaktadır. Araştırmacılar bu olumsuz davranışların engellenebilmesi için iş tatmini kavramına odaklanmışlardır (Dormann \& Zapf, 2001:483).

Örgütsel bağlılık kavramı, psikoloji, sosyoloji, sosyal psikoloji ve örgütsel davranış gibi farklı disiplinlerdeki araştırmacılar tarafından tanımlanmıştı (Kök, 2006:297). Bu yaklaşımlar içerisinde literatürde en çok kabul gören ve kullanılan yaklaşım Allen \& Meyer'in üç boyutlu örgütsel bağlılık modelidir (Bolat \& Bolat, 2008:78). Allen \& Meyer örgütsel bağlılığı; duygusal, devamlılık ve normatif bağlılık olarak incelemiştir. Duygusal bağlılık, çalışanların örgütlerinin hedeflerini, amaçlarını ve değerlerini benimsedikleri oranda hissettikleri bağlılıktır. Devamlılık bağlılı̆̆ı, çalışanların örgütlerine yaptıkları yatırımların sonucunda artan örgütten ayrılma maliyetlerini göz önünde bulundurarak geliş̧irdikleri bağl1lıktır. 
Normatif bağlılık ise çalışanın örgüt bünyesinde bulunmayı kendisi için bir görev olarak görmesi ve örgütüne bağlılık göstermenin doğru olduğunu hissetmesidir. Bu bağlılık türü de örgütten ayrılmanın neticesinde ortaya çıkacak kayıpların hesaplanması sürecinden etkilenmektedir (Bayram, 2005).

\subsection{Performans}

Performans kavramı bilimsel çalışmalarda farklı türlerde ele alınmış olmasına rağmen, uygulama açısından en çok görev performansı ve bağlamsal performansın dikkat çektiği görülmektedir (Jawahar \& Carr, 2007; Borman \& Motowidlo, 1997).

Görev performansı, verilen bir işle ilgili görev ve sorumlulukların yerine getirilmesi olarak tanımlanmaktadır. Borman \& Motowidlo (1993) görev performansını formel olarak işin bir parçası olarak kabul edilen ve kurumun temel yeteneğine katkıda bulunan faaliyetler olarak tanımlamışlardır. Görev performansı, kuruluşun faaliyetlerine katkıda bulunan süreçlerin teknik ekipmanlar, malzemeler ve emek kullanılarak görevli çalışan tarafından yerine getirilmesidir (Borman \& Motowidlo, 1997). Bu anlamda görev performansı daha çok işin uzmanlık ve teknik yönüyle ilgilidir.

Bağlamsal performans ise, çalışanın iş tanımında yer almayan ancak işletme için önemli olduğuna inanılan süreçlerin yerine getirilmesinde gönüllü olunması ve bu noktada kurumdaki diğer kişilerle yardım ve iş birliği yapılması olarak tanımlanmaktadır (Borman \& Motowidlo, 1997).

\section{Hipotez Geliştirme}

\subsection{Kişi Örgüt Uyumu ile Performans Arasındaki İlişki}

Çalışanların gösterdikleri bireysel performanslar, kurumun genel performansını belirlemede önemli bir etkendir. Çalıştığı kurumun değerleri ile kendi değerleri uygun bir şekilde uyuşmayan çalışanların düşük iş performansına sahip olacağı beklendiğinden (Farooqui \& Nagendra, 2014), son yıllarda kişi-örgüt uyumu ile performans arasındaki ilişkiler dikkat çekici konular arasında yer almaktadır.

Kristof (1996), kişi-örgüt uyumunun iş performansındaki önemli değişimleri açıklayacağını ileri sürmüştür. Goodman \& Svyantek (1999) yaptıkları çalışmada, çalışanların kişi-örgüt uyumlarının, yöneticiler tarafından yapılan bağlamsal ve görev performansı değerlendirmelerini etkileyebileceği bulgusuna ulaşmışlardır. Bunun sebebini ise yöneticilerin daha yüksek kişi-örgüt uyumuna sahip olduğunu düşündükleri çalışanlarının daha yüksek görev ve bağlamsal performans gösterecekleri yönündeki algılarıdır. Bu yüzden düşük kişiörgüt uyumuna sahip olan çalışanlar daha düşük performans değerlendirmesi almışlardır. Bu argümanlara dayanarak;

H1: Kişi-örgüt uyumu ile görev performansı arasında pozitif bir ilişki bulunmaktadır.

H2: Kişi-örgüt uyumu ile bă̆lamsal performans arasında pozitif bir ilişki bulunmaktadır.

\subsection{Kişi Örgüt Uyumu ile İş Tutumları Arasındaki}

İnsanlar işletmelere katılma ve işletmelerde bireyleri işe alma kararlarını, mevcut özelliklere dayanarak vermektedirler. Geleneksel görüşe göre seçim süreçleri, geçmiş 
deneyim, zekâ, bilgi, beceri ve yetenekler gibi işle ilgili özellikleri değerlendirmekte ve bu değerlendirmelerin, işletmeler için yüksek performans ve bireyler için ise yüksek tatmin gibi beklenen çıktılarının olması beklenir. Bu seçim kararları doğru verilmediğinde yani, kişilerin içerisinde bulundukları çevrelerine uymadıklarını hissettiklerinde, yetersizlik ve endişe duyguları yaşarlar. Doğru seçim kararları verilerek çevreleriyle uyumlu oldukları zaman ise daha fazla olumlu ve daha az olumsuz duygular yaşarlar ve bulundukları ortamda kalmayı tercih ederler. Bu nedenle, yüksek kişi-örgüt uyumunun daha yüksek iş tatminine ve işletmeye bağlanarak daha uzun süre mevcut işinde kalmayı tercih etmelerine neden olabilir (Chatman, 1991:464).

$\mathrm{Bu}$ teorik beklentiler doğrultusunda, literatürde kişi-örgüt uyumu ile iş tutumları arasında pek çok çalışma yürütülmüştür. Bu çalışmalarda genel olarak kişi-örgüt uyumu bağımsız değişken iş tatmini ve örgütsel bağlılık ise bağımlı değişkenler olarak dikkate alınmıştır. Örneğin Chatman (1991), bir çalışanın örgütüne bir bütün olarak uygunluğunun nasıl tesis edildiğini ve sürdürüldüğünü ve bunun sonuçlarının ise neler olduğunu derinlemesine incelediği çalışmasında, ABD'deki en büyük sekiz denetim şirketindeki 171 başlangıç seviyesindeki denetçinin kariyer gelişimlerini izlemiş ve değerlendirmeler yapmıştır. Chatman (1991) çalışması sonucunda elde ettiği bulgulara göre yüksek kişi-örgüt uyumunun, daha yüksek iş tatminiyle ve daha uzun süreler işletmede kalma kararının verilmesiyle ilişkili olduğu bulgusuna ulaşmıştır. Ek olarak, Verquer vd. (2003) tarafından gerçekleştirilen meta analizi çalışmasının sonuçlarına göre kişi-örgüt uyumunun iş tatmini ve örgütsel bağlılık ile pozitif ve işten ayrılma niyeti ile de negatif ilişkili olduğu bulgusuna ulaşılmıştır.

$\mathrm{Bu}$ argümanlara dayanarak;

H3: Kişi-örgüt uyumu ile iş tatmini arasında pozitif bir ilişki bulunmaktadır.

H4: Kişi-örgüt uyumu ile örgütsel bağlllık arasında pozitif bir ilişki bulunmaktadır.

\section{3. İş Tutumları ile Performans Arasındaki İlişki}

Sosyal değişim teorisi, bir çalışanın işinden tatmin olduğunu hissettiğinde, pozitif iş performansı göstererek kurumuna katkı sağlayacağını ifade etmektedir (Peng vd., 2014). Bağlamsal davranışlar bir çalışanın kurumuna yaptığı gönüllü katkılardır, bu nedenle bir çalışanın işinden memnun olması durumunda, çalışanın bağlamsal performansı aracılığıyla başkalarına yardım ederek karşılık vermesi beklenmektedir (Edwards vd., 2008).

Benzer şekilde örgütlerdeki performans problemlerini iyileştirmede örgütsel bağlılığın önemine de dikkat çekilmektedir (Ostroff, 1992). Yüksek örgütsel bağlılığın iş performansını artırdığına yönelik literatürde çeşitli bulgular mevcuttur (Kalkavan \& Katrinli, 2014). Benzer şekilde Randall (1987)'da yüksek örgütsel bağlılık seviyesinin örgüt açısından yüksek performansa katkı sağlayacağını ileri sürmektedir.

$\mathrm{Bu}$ argümanlara dayanarak;

H5: İs tatmini ile görev performansı arasında pozitif bir ilişki bulunmaktadır.

H6: İs tatmini ile bă̆lamsal performans arasında pozitif bir ilişki bulunmaktadır.

H7: Örgütsel bă̆lılık ile görev performansı arasında pozitif bir ilişki bulunmaktadır.

H8: Örgütsel bağlılık ile bă̆lamsal performans arasında pozitif bir ilişki bulunmaktadır. 


\section{Şekil 1: Araştırma Modeli}

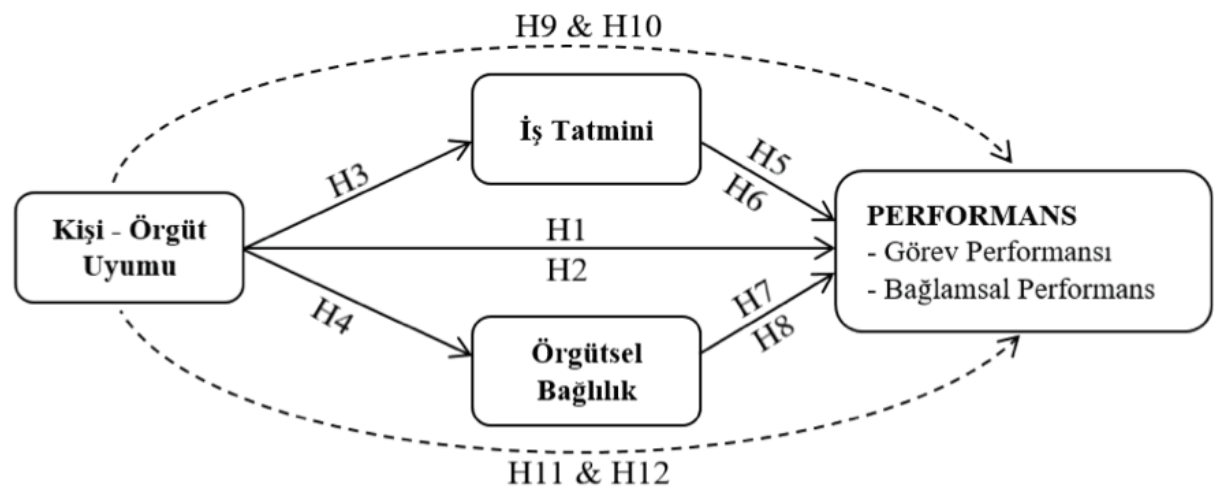

\section{4. İş Tutumlarının Aracılık Rolleri}

Kişi-örgüt uyumunun işe karşı tutumlar yoluyla iş performansı üzerinde dolaylı bir etkisinin de olabileceği yönündedir. Arthur vd. (2006)'nin yaptıkları meta analizi ile kişiörgüt uyumu ile performans arasındaki ilişkide iş tutumlarının aracı rollerinin olduğuna dair bulgulara ulaşılmıştır.

Öcel (2013) ise kişi-örgüt uyumu, algılanan örgütsel prestij ve örgüt kimliğinin gücü ile bağlamsal performans arasındaki ilişkilerde devamlılık bağlılı̆̆ı, duygusal bağlılık ve normatif bağlılık olarak alt boyutları bazında örgütsel bağlılığın aracı rolünü incelemiştir. Yapılan çalışmanın sonunda normatif bağlılık ve duygusal bağlılığın kişi-örgüt uyumu ve diğer değişkenler ile bağlamsal performans arasındaki ilişkide aracı rol oynadığı ancak devamlılık bağlılığının ise böyle bir aracı rolünün olmadığg bulgusuna ulaşılmıştır.

$\mathrm{Bu}$ argümanlara dayanarak;

H9: İs tatmini, kişi örgüt uyumu ve görev performansı arasındaki ilişkide aracı rol oynamaktadır.

H10: İ̧s tatmini, kişi örgüt uyumu ve bağlamsal performans arasındaki ilişkide aracı rol oynamaktadır.

H11: Örgütsel bă̆lllık, kişi örgüt uyumu ve görev performansı arasındaki ilişkide aracı rol oynamaktadir.

H12: Örgütsel bă̆lılık, kişi örgüt uyumu ve bă̆lamsal performans arasındaki ilişkide aracı rol oynamaktadır.

\section{Araştırma}

\subsection{Araştırmanın Amacı ve Önemi}

Kişisel özellikler ile örgütsel özellikler arasındaki uyumu ifade eden kişi-örgüt uyumu, örgütsel davranış, insan kaynakları ve endüstriyel psikoloji disiplinleri içerisinde oldukça 
önemli bir yere sahiptir. Bu öneminin altında yatan temel sebepler kişi örgüt uyumunun; işe yönelik tutumlar ve bireylerarası dinamikler açısından oldukça önemli ve pozitif sonuçları beraberinde getirmesi olarak ifade edilebilir (Behram \& Dinç, 2014). Daha önce yapılmış çalışmalarda iş tutumlarının, iş performansının farklı kavramlarla olan ilişkilerinde aracı rollerinin olup olmadığının incelendiği görülmektedir. Aynı şekilde kişi-örgüt uyumu ile iş tutumları arasındaki ilişkilerin de incelendiği görülmektedir. Ancak yapılan literatür incelemesinde iş tutumlarının kişi-örgüt uyumu ile iş performansı arasındaki ilişkideki aracı rollerinin yeteri kadar incelenmediği görülmüştür. Önceki çalışmalarda ya iş tutumlarından sadece birinin dikkate alındığ 1 ya da iş performansının sadece bir boyut üzerinden ölçüldüğü görülmektedir. Bu araştırmada daha geniş bir bakış açısı benimsenerek kişi-örgüt uyumu ile görev ve bağlamsal performanslar arasındaki ilişkilerde iş tutumlarının aracı rollerinin olup olmadığının incelenmesi hedeflenmektedir.

\section{2. Ölçüm ve Örnekleme}

Araştırma modelinde belirtilen ilişkilerin analiz edilmesi için Marmara Bölgesi’nde kamu ve özel sektörde çalışan kişilerden anket tekniği ile veri toplanmıştır. Kişi-örgüt uyumu ve iş tutumları kavramlarının hem kamu hem de özel sektörde çalışanlar açısından önemli olması göz önüne alınarak, çalışmanın ana kitlesi için spesifik bir örneklem grubu seçilmemiş, heterojen bir örneklem grubu ile araştırma gerçekleştirilmiştir. Geçersiz olan anketler değerlendirmeden çıkarıldıktan sonra, kamu sektöründen 116 adet, özel sektörden ise 215 adet olmak üzere toplam 331 adet anket veri analizine dâhil edilmiştir. Çalışmanın evrenini Kocaeli ve İstanbul şehirlerinde tam zamanlı çalışanlar oluşturmaktadır. İstanbul ve Kocaeli şehirlerinin seçilme nedeni Türkiye ekonomisine katkı sağlayan ihracatın yoğun olarak yapıldığı şehirler olmasıdır. Ancak, zaman, ulaşılabilirlik ve maliyet zorlukları açısından evrenin tamamı yerine seçilen örneklem ile araştırma gerçekleştirilmiştir. Çalışmanın örneklemini kolayda örneklem yoluyla ulaşılan çalışanlar oluşturmaktadır.

Örneklemde yer alan katılımcıların \%53,1'i erkek, \%40,1'i 26-30 yaş arası, kişilerden oluşmaktadır. Medeni durum olarak \%52,6'sı evlidir. Eğitim durumu olarak, 55,9'u lisans, mezunudur. Mevcut iş yerlerindeki hizmet süresi olarak \%49,2'si 1-3 yıl arası çalışma tecrübesine sahiptir. Katılımcıların \%65,3'ü personel olarak mevcut iş yerlerinde görev almaktadırlar.

Geliştirilen araştırma modelini test etmek için literatürde var olan geçerliliği ve güvenilirliği önceden test edilmiş ölçekler kullanılmıştır. Kişi-örgüt uyumu, Cable \& De Rue (2002) tarafından geliştirilen 3 maddelik Kişi-Örgüt Uyumu Ölçeği ile ölçülmüştür. Ölçek, katılımcıların kendileriyle örgütleri arasındaki uyum algılarını ölçmeye odaklanmaktadır. Ölçeğe ilişkin sorulara örnek olarak "Kişisel değerlerim kurumumun değer ve kültürüyle örtüşür.” gösterilebilir. İş tatmini, Schwepker (2001) tarafından geliştirilen 3 maddeli İş Tatmini Ölçeği ile ölçülmüştür. Katılımcılardan işleriyle ilgili memnuniyet seviyelerini derecelendirmeleri istenmiştir. Ölçeğe ilişkin sorulara örnek olarak "İşim tatmin edicidir." gösterilebilir. Örgütsel bağlılı̆̆ı ölçmek için Hartline \& Ferrell (1996), Netenmeyer vd. (1997) ve Babin \& Boles (1998) tarafından geliştirilen, güvenirlik, geçerlilik ve Türkçeye uyarlaması Toklu (2016) tarafından gerçekleştirilmiş olan 4 ifadelik ölçek kullanılmıştır. Ölçeğe ilişkin sorulara örnek olarak "Bu kuruma karşı güçlü bir bağlılık duyuyorum.” gösterilebilir. Görev performansı, Williams \& Anderson (1991) tarafından geliştirilen 7 maddeli Görev Performansı 
Ölçeği ile ölçülmüştür. Katılımcılardan işleriyle ilgili görev performanslarını değerlendirmeleri istenmiştir. Ölçeğe ilişkin sorulara örnek olarak "Benden beklenen asgari (temel) performans beklentilerini yerine getiririm.” gösterilebilir. Son olarak bağlamsal performansı ölçmek için Boorman \& Motowidlo (1993) tarafından geliştirilen 16 sorulu ölçek kullanılmıştır. Ölçeğe ilişkin sorulara örnek olarak "Gerek kurumumun etkinliği gerekse çalışma arkadaşlarıma yardım etmek için gönüllü olarak işimin gereğinden fazlasını yaparım.” gösterilebilir.

Anket soruları ilk olarak İngilizceden Türkçeye ardından Türkçeden İngilizceye iki kişi tarafından ayrı ayrı çevrilmiştir. Çevirisi yapılan sorular örgütsel davranış alanında çalışan iki Türk akademisyen tarafından tekrar değerlendirilmiş ve teoriye uyumlu olarak son hali verilmiştir. Daha sonra çalışan beş yüksek lisans öğrencisinden soruların içeriği ve anlamlılığını değerlendirmesi istenmiştir. Yanıtlayıcılar soruları ve içerikleri anlamada zorluk çekmediklerini ifade ettikten sonra anketler çoğaltılarak dağıtılıp toplanmıştır.

\section{3 Ölçüm Geçerliliği ve Güvenilirliği}

Araştırma kapsamında ihtiyaç duyulan verilerin elde edilmesinden ve kontrol edilerek analize uygun biçimde düzenlenmesinden sonra, kullanılan ölçeklerin güvenilirlik ve geçerliliklerini değerlendirme aşamasına geçilmiştir.

Araştırma modelinde yer alan faktörlerin geçerliliklerini incelemek için AMOS yazılım programı vasıtasıyla doğrulayıcı faktör analizi (Confirmatory Factor Analysis - CFA) yapılmıştır. CFA, en yüksek olabilirlik tahmin yöntemi (maximum likelihood estimation) ile hesaplamalar yaparak veriyi oluşturan faktörlerin yapısına ait iyilik indekslerinin değerlendirilmesini sağlamaktadır (Ayar, 2016:95).

Tablo 1: Güvenilirlik ve Geçerlilik Katsayıları

\begin{tabular}{lccccccc}
\hline Değişkenler & Ortalama & St. Sapma & $\mathbf{1}$ & $\mathbf{2}$ & $\mathbf{3}$ & $\mathbf{4}$ & $\mathbf{5}$ \\
\hline 1. Kişi-Örgüt Uyumu & 3,26 & 1,04 & $(0,87)$ & & & & \\
\hline 2. İş Tatmini & 3,72 & 1,01 &, $510^{*}$ & $(0,85)$ & & & \\
\hline 3. Örgütsel Bağll1ık & 3,25 & 1,17 &, $614^{*}$ &, $608^{*}$ & $(0,90)$ & & \\
\hline 4. Bağlamsal Perf. & 4,28 & 0,58 &, $302^{*}$ &, $473^{*}$ &, $312^{*}$ & $(0,74)$ & \\
\hline 5. Görev Performansı & 4,43 & 0,62 &, $111^{*}$ &, $321^{*}$ &, $174^{*}$ &, $753^{*}$ & $(0,78)$ \\
\hline AVE & - & - &, 77 &, 75 &, 82 &, 55 &, 61 \\
\hline CR & - & - &, 90 &, 90 &, 94 &, 91 &, 90 \\
\hline Cronbach's & - & - &, 90 &, 90 &, 95 &, 90 &, 88 \\
\hline
\end{tabular}

* Korelasyon 0.01 düzeyinde anlamlı (2-yönlü) Parantez içerisindeki değerler AVE'nin karekökü değerleridir.

Tablo 1'de raporlanan bulgulara göre, çapraz yüklere sahip problemli sorular elendikten sonra elde edilen sonuç modelinin, beklenen kesme değerleri ile oldukça uyumlu olduğu görülmüştür: $\chi 2(265)=513,967, \mathrm{CFI}=.960, \mathrm{IFI}=.960, \mathrm{TLI}=.955, \chi 2 / \mathrm{df}=1,939$ ve RMSEA $=$ .053 , PNFI 0.814 olarak hesaplanmıştır (Hair vd., 2009). Ayrıca bütün sorular kendi değişkenine anlamlı (en düşük t- değeri 10.34) ve oldukça yüksek faktör yükü ile yüklenmiştir (en düşük faktör yükü 0.539). Göstergelerin istatistiki olarak anlamlı bir şekilde kendi faktörlerine yüklenmesi yakınsama geçerliliği için kanıt sağlamaktadır. 
Tablo 1'de ayrıca ortalama ve standart sapma ile birlikte ortalama açıklanan varyans (Average Variance Extracted - AVE) ve AMOS-tabanlı bileşik güvenilirlik (Composite Reliability-CR) değerleri ve güvenilirlik analizleri (Cronbach Alfa) de raporlanmıştır. AVE ve CR değerleri, Hair vd. (2009) tarafından önerilen değerlerin (AVE için 0.50; CR için 0.70) üstünde elde edilmiştir. Bununla birlikte Fornell \& Larcker (1981) önerdiği gibi her bir değişkenin AVE karekökünün örtük değişkenlerin korelasyonundan büyük olduğu hesaplanmıştır. Kısacası sunulan istatistiki değerler ve bu değerler üzerinden varılan yargı çerçevesinde, araştırmada kullanılan ölçeklerin yeterli düzeyde güvenilirlik ve yakınsama ve ayrışma geçerliliğine sahip olduğu ortaya koyulmuştur.

\subsection{Hipotez Testleri}

Şekil 1'de gösterilen kavramsal model kapsamındaki ilişkileri test etmek amacıyla AMOS programı üzerinden yapısal eşitlik analizi gerçekleştirilmiştir. Tablo 2'de kişi-örgüt uyumu, iş tatmini, bağlamsal performans ve görev performansı arasındaki ilişkiler ve Tablo 3 'de ise kişi-örgüt uyumu, örgütsel bağlılık, bağlamsal performans ve görev performansı arasındaki ilişkiler gösterilmektedir.

Tablo 2 incelendiğinde kavramsal modelin veri ile uyum içinde olduğu görülmektedir. CFI, IFI ve TLI değerleri kesme noktası 0,90 'a çok yakın ya da üzerinde olduğundan kabul edilebilir düzeydedir. Ki-kare ve serbestlik derecesi oranı önerildiği gibi 5 'ten küçük bir değerdir $(\chi 2 /$ d.f.= 3,408). RMSEA değerinin 0.08 ile 0.05 arasında değer alması ise kabul edilebilir bir uyum iyiliği değerine sahip olduğunu göstermektedir. Tablo 2'deki analizde bu değer 0,08 olarak elde edildiği için kabul edilebilir değer düzeyindedir. Ayrıca PNFI kesme değeri olan 0,70 değerinin üzerindedir.

Tablo 2: Yol Modeli (Kişi-Örgüt Uyumu, İş Tatmini, Bağlamsal ve Görev Performansı)

\begin{tabular}{|c|c|c|c|c|c|}
\hline Hipotezler & Yol & & & Yol değeri & Sonuç \\
\hline $\mathrm{H} 3$ & Kişi-Örgüt Uyumu & $\rightarrow$ & İş Tatmini & $.588 * * *$ & Desteklendi \\
\hline H5 & İş Tatmini & $\rightarrow$ & Görev Performansı & $.228 * * *$ & \multirow{2}{*}{ Desteklendi } \\
\hline H6 & İş Tatmini & $\rightarrow$ & Bağlamsal Performans & $.327 * * *$ & \\
\hline \multicolumn{6}{|c|}{$\chi 2(186)=633,855 ;$ CFI $=.90 ;$ IFI $=.90 ;$ TLI $=.89 ; \chi 2 / \mathrm{df}=3,408 ; \mathrm{PNFI}=.77 ; \mathrm{RMSEA}=.08$} \\
\hline
\end{tabular}

Tablo 3: Yol Modeli (Kişi-Örgüt Uyumu, Örgütsel Bağlılık, Bağlamsal ve Görev Performansi)

\begin{tabular}{|c|c|c|c|c|c|}
\hline Hipotezler & Yol & & & Yol değeri & Sonuç \\
\hline $\mathrm{H} 4$ & Kişi-Örgüt Uyumu & $\rightarrow$ & Örgütsel Bağlılık & $.736 * * *$ & Desteklendi \\
\hline $\mathrm{H} 7$ & Örgütsel Bağlılık & $\rightarrow$ & Görev Performansı & $.103 * * *$ & \multirow{2}{*}{ Desteklendi } \\
\hline H8 & Örgütsel Bağlılık & $\rightarrow$ & Bağlamsal Performans & $.184 * * *$ & \\
\hline \multicolumn{6}{|c|}{$\chi 2(206)=685,229 ; \mathrm{CFI}=.91 ; \mathrm{IFI}=.91 ; \mathrm{TLI}=.90 ; \chi 2 / \mathrm{df}=3,326 ; \mathrm{PNFI}=.78 ; \mathrm{RMSEA}=.08$} \\
\hline
\end{tabular}


İş tutumlarının öncülü olarak ele alınan kişi-örgüt uyumu ile iş tatmini değişkenleri arasındaki ilişkinin incelendiği $\mathrm{H} 3$ hipotezinde, kişi-örgüt uyumunun iş tatmini $(\beta=.588$; $\mathrm{p}<$ .01) ile pozitif ilişki içerisinde olduğu görülmektedir. Dolayısıyla H3 hipotezi desteklenmektedir. Görev ve bağlamsal performansın öncülü olarak dikkate alınan iş tutumlarından iş tatmini ile bu değişkenler arasındaki ilişki incelendiğinde ise iş tatmininin görev performansı $(\beta=.228$; $\mathrm{p}<.01)$ ile ve bağlamsal performans $(\beta=.327 ; \mathrm{p}<.01)$ ile pozitif ilişki içerisinde olduğu bulgusuna ulaşılmıştır. Dolayısıyla H5 ve H6 hipotezleri de desteklenmiştir.

İş tutumlarının öncülü olarak ele alınan kişi-örgüt uyumu ile örgütsel bağlılık değişkenleri arasındaki ilişkinin incelendiği H4 hipotezinde, kişi-örgüt uyumunun örgütsel bağlılık $(\beta=.736 ; \mathrm{p}<.01)$ ile pozitif ilişki içerisinde olduğu görülmektedir. Dolayısıyla H4 hipotezi desteklenmektedir. Görev ve bağlamsal performansın öncülü olarak dikkate alınan iş tutumlarından örgütsel bağlılık ile bu değişkenler arasındaki ilişki incelendiğinde ise örgütsel bağlılı̆̆ın görev performansı $(\beta=.103 ; \mathrm{p}<.01)$ ile ve bağlamsal performans $(\beta=.184 ; \mathrm{p}<.01)$ ile pozitif ilişki içerisinde olduğu bulgusuna ulaşılmıştır. Dolayısıyla H7 ve H8 hipotezleri de desteklenmiştir.

İş tutumları olarak dikkate alınan iş tatmini ve örgütsel bağlılığın, kişi örgüt uyumu ile bağlamsal performans ve görev performansı arasındaki ara değişken etkisi Baron \& Kenny (1986)'nin önerdiği yaklaşım takip edilerek test edilmiştir. Bu yaklaşımda, bağımsız bir değişken olan X ile bağımlı bir değişken olan Y arasındaki ilişkiye üçüncü bir değişken olarak M dâhil olduğunda, eğer aşağıdaki dört şart sağlanıyorsa, M değişkeninin X ile Y arasındaki ilişkide aracılık etkisine sahiptir denilebilir. Bu şartlar şunlardır: (1) X ile Y arasında anlamlı bir ilişki olmalı. (2) X ile M arasında anlamlı bir ilişki olmalı. (3) X kontrol altında tutulurken M ile Y hâlâ anlamlı bir şekilde ilişki olmalı ve (4) M kontrol altında tutulurken X ile Y arasındaki ilişki ortadan kalkmalı ya da ilişkinin gücü azalmalıdır.

\section{Tablo 4: İş Tatmini Ara Değişken Etkisi}

\begin{tabular}{|c|c|c|c|c|}
\hline İlişki & & Model A & Model B & Model C \\
\hline Kişi-Örgüt Uyumu & $\rightarrow$ Görev Performansı & $.100 * * *$ & & $-.078 *$ \\
\hline Kişi-Örgüt Uyumu & $\rightarrow$ Bağlamsal Performans & $.207 * * *$ & & .002 \\
\hline Kişi-Örgüt Uyumu & $\rightarrow$ İş Tatmini & & $.583 * * *$ & $.591 * * *$ \\
\hline İş Tatmini & $\rightarrow$ Görev Performansı & & & $.278 * * *$ \\
\hline \multirow[t]{7}{*}{ İş Tatmini } & $\rightarrow$ Bağlamsal Performans & & & $.330 * * *$ \\
\hline & & $\begin{array}{c}\chi 2(133)= \\
558,268\end{array}$ & \multirow{6}{*}{$\begin{array}{c}\text { Full } \\
\text { Model }\end{array}$} & $\begin{array}{c}\chi^{2}(184)= \\
630,778\end{array}$ \\
\hline & & $\mathrm{CFI}=.88$ & & $\mathrm{CFI}=.90$ \\
\hline & & $\mathrm{IFI}=.88$ & & $\mathrm{IFI}=.90$ \\
\hline & & $\mathrm{PNFI}=.74$ & & $\mathrm{PNFI}=.76$ \\
\hline & & $\chi 2 / \mathrm{df}=4.19$ & & $\chi 2 / \mathrm{df}=3.42$ \\
\hline & & RMSEA $=.09$ & & RMSEA $=.08$ \\
\hline
\end{tabular}

$* \mathrm{p}<.1, * * \mathrm{p}<.05, * * * \mathrm{p}<.01$ 
"2" ve "3" numaralı adımlar aracılık etkisinin tespitinde temel adımlar olarak gösterilirken, "4" numaralı adım ise aracılık etkisinin derecesini yani tam ya da kısmi aracı etkinin olup olmadığını göstermektedir. Eğer M kontrol altında tutulurken X ile Y arasındaki ilişki tamamen ortadan kalkıyor yani ilişki istatistiksel olarak anlamsızlaşıyorsa, tam aracılık etkisinden, eğer bu ilişki istatistiksel olarak anlamsızlaşmıyor ancak, ilişkinin gücü yani beta katsayısının değeri mutlak değer olarak azalıyorsa kısmi aracılık etkisinden söz edilebilmektedir.

Tablo 5: Örgütsel Bağlılık Ara Değişken Etkisi

\begin{tabular}{|c|c|c|c|c|}
\hline \multicolumn{2}{|l|}{ İlişki } & \multirow{2}{*}{$\begin{array}{l}\text { Model A } \\
.100 * * *\end{array}$} & \multirow[t]{2}{*}{ Model B } & \multirow{2}{*}{$\begin{array}{c}\text { Model C } \\
.036\end{array}$} \\
\hline Kişi-Örgüt Uyumu & $\rightarrow$ Görev Performansı & & & \\
\hline Kişi-Örgüt Uyumu & $\rightarrow$ Bağlamsal Performans & $.207 * * *$ & & $.126 * *$ \\
\hline Kişi Örgüt Uyumu & $\rightarrow$ Örgütsel Bağlılık & & $.734 * * *$ & $.734 * * *$ \\
\hline Örgütsel Bağlılık & $\rightarrow$ Görev Performansı & & & $.078 *$ \\
\hline \multirow[t]{7}{*}{ Örgütsel Bağlılık } & $\rightarrow$ Bağlamsal Performans & & & $.104 * *$ \\
\hline & & $\begin{array}{c}\chi 2(133)= \\
558,268\end{array}$ & \multirow{6}{*}{$\begin{array}{l}\text { Full } \\
\text { Model }\end{array}$} & $\begin{array}{c}\chi^{2}(204)= \\
678,891\end{array}$ \\
\hline & & $\mathrm{CFI}=.88$ & & $\mathrm{CFI}=.91$ \\
\hline & & $\mathrm{IFI}=.88$ & & IFI $=.91$ \\
\hline & & $\mathrm{PNFI}=.74$ & & $\mathrm{PNFI}=.77$ \\
\hline & & $\chi^{2 / \mathrm{df}}=4.19$ & & $\chi 2 / \mathrm{df}=3.32$ \\
\hline & & RMSEA $=.09$ & & RMSEA $=.08$ \\
\hline
\end{tabular}

$* \mathrm{p}<.1, * * \mathrm{p}<.05, * * * \mathrm{p}<.01$

Baron \& Kenny (1986)'nin önerdiği yaklaşımdan hareketle, iş tutumlarından iş tatminin kişi-örgüt uyumu ile görev ve bağlamsal performanslar arasındaki ilişkideki ara değişken etkisini incelemek amacıyla Tablo 4'de gösterilen üç farklı YEM modeli geliştirilmiştir. Buna göre:

a) Kişi-örgüt uyumu (X) ile görev ve bağlamsal performansları (Y) içeren Model A incelendiğinde; kişi-örgüt uyumunun görev performansı $(\beta=.100 ; p<.01)$ ile ve bağlamsal performans $(\beta=.207$; $\mathrm{p}<.01)$ ile pozitif ilişki içerisinde olduğu bulgusuna ulaşılmıştır. $\mathrm{Bu}$ sonuçlardan $\mathrm{H} 1$ ve $\mathrm{H} 2$ hipotezlerinin desteklendiği bulgusuna da ulaşılmaktadır.

b) Kişi-örgüt uyumu ile (X) ile iş tatminini (M) içeren Model B'de, kişi-örgüt uyumunun iş tatmini $(\beta=.583 ; \mathrm{p}<.01)$ ile pozitif ilişkili olduğu görülmektedir.

c) Model C'de ise görüldüğü üzere, kişi-örgüt uyumu değişkeni kontrol altına alındıktan sonra iş tatminin görev performansı $(\beta=.69, \mathrm{p}<.01)$ ve bağlamsal performans $(\beta=.69, \mathrm{p}<.01)$ ile pozitif ilişkili olduğu tespit edilmektedir. Ayrıca iş tatmini kontrol altına alındıktan sonra ise kişi-örgüt uyumu değişkeninin bağlamsal performans üzerindeki etkisi ortadan kalkmakta ve görev performansı üzerindeki etkisi ise azaltmaktadır. 
$\mathrm{Bu}$ bulgulara göre iş tatmini kişi-örgüt uyumu ile bağlamsal performans arasındaki ilişkide tam ara değişken etkisine, kişi-örgüt uyumu ile görev performansı arasındaki ilişkide ise kısmi ara değişken etkisine sahiptir bulgusuna ulaşılmaktadır. Dolayısıyla H9 ve H10 desteklenmektedir.

İkinci olarak iş tutumlarından örgütsel bağlılığın kişi-örgüt uyumu ile görev ve bağlamsal performanslar arasındaki ilişkideki ara değişken etkisini incelemek amacıyla Tablo 5'de gösterilen üç farklı YEM modeli geliştirilmiştir. Buna göre:

a) Kişi-örgüt uyumu (X) ile görev ve bağlamsal performansları (Y) içeren Model A incelendiğinde; kişi-örgüt uyumunun görev performansı $(\beta=.100 ; p<.01)$ ile ve bağlamsal performans $(\beta=.207 ; \mathrm{p}<.01)$ ile pozitif ilişki içerisindedir.

b) Kişi-örgüt uyumu ile (X) ile örgütsel bağlılığı (M) içeren Model B'de, kişi-örgüt uyumunun örgütsel bağlılık $(\beta=.734 ; \mathrm{p}<.01)$ ile pozitif ilişkili olduğu görülmektedir.

c) Model C'de ise görüldüğü üzere, kişi-örgüt uyumu değişkeni kontrol altına alındıktan sonra örgütsel bağlılığın görev performansı $(\beta=.078, \mathrm{p}<.10)$ ve bağlamsal performans $(\beta=.104, \mathrm{p}<.05)$ ile pozitif ilişkili olduğu tespit edilmektedir. Ayrıca örgütsel bağlılık kontrol altına alındıktan sonra ise kişi-örgüt uyumu değişkeninin görev performansı üzerindeki etkisi ortadan kalkmakta ve bağlamsal performans üzerindeki etkisi ise azaltmaktadır.

Bu bulgulara göre örgütsel bağlılık kişi-örgüt uyumu ile görev performansı arasındaki ilişkide tam ara değişken etkisine, kişi-örgüt uyumu ile bağlamsal performans arasındaki ilişkide ise kısmi ara değişken etkisine sahiptir bulgusuna ulaşılmaktadır. Dolayısıyla H11 ve H12 desteklenmektedir.

\section{Tartışma}

Örgüt ve bireyin uzun yillar beraber olma ortak niyetini ifade eden kişi-örgüt uyumu ile ilgili özellikle son 30 yıllık dönemde önemli araştırmalar gerçekleştirilmiştir. Bu artışların altında yatan temel mantık, kişisel özellikler ile örgütün özellikleri arasındaki uyumun önemli bireysel ve örgütsel sonuçlara katkıda bulunmasıdır (Borman vd., 1997:327). Örneğin Chatman (1991) çalışması ile yükssek kişi-örgüt uyumunun, daha yüksek iş tatminiyle ve daha uzun süreler işletmede kalma kararının verilmesiyle ilişkili olduğu bulgusuna ulaşmıştır. Benzer şekilde Vancouver \& Schmitt (1991) ise kişi-örgüt uyumunun hem iş tatmini hem de örgütsel bağlılık ile pozitif ilişkili olduğu bulgusuna ulaşmıştır.

Ayrıca, Goodman \& Svyantek (1999) yaptıkları çalışmada çalışanların kişi-örgüt uyumlarının, yöneticiler tarafından yapılan bağlamsal ve görev performansı değerlendirmelerini etkileyebileceği bulgusuna ulaşmışlardır. Bunun sebebini ise yöneticilerin daha yüksek kişiörgüt uyumuna sahip olduğunu düşündükleri çalışanlarının daha yüksek görev ve bağlamsal performans gösterecekleri yönündeki algılarıdır.

Örgütsel davranış literatüründe kurumlardaki performans problemlerini iyileştirmede iş tutumlarının önemine de dikkat çekilmektedir. Örneğin Ostroff (1992) tarafından yürütülen çalışmada örgütsel bağlılık ile birlikte iş tatmini ve diğer iş tutumlarının da performans üzerindeki etkisinin varlığı ortaya koyulmuştur. 
Bu çalışmada ise literatürle uyumlu bir şekilde bu bulgular elde edilmiştir; (1) kişi-örgüt uyumu görev ve bağlamsal performans ile pozitif bir ilişkiye sahiptir, (2) kişi-örgüt uyumu iş tutumları ile pozitif bir ilişkiye sahiptir, (3) iş tutumları görev ve bağlamsal performans ile pozitif ilişkilidirler ve (4) iş tutumları, kişi-örgüt uyumu ile görev ve bağlamsal performans arasındaki ilişkide aracı rol oynamaktadırlar.

$\mathrm{Bu}$ bulgulara göre çalışanlar kişi-örgüt uyumuna sahip olduklarında işten duydukları tatmin ve örgütsel bağlılık düzeyleri artmakta ve temel iş sorumluluklarını içeren görev

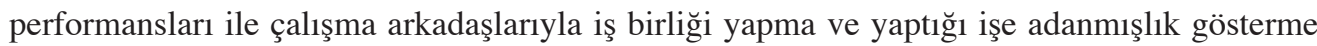
gibi işe özgü olmayan davranışlarını içeren bağlamsal performansları da artmaktadır. Benzer şekilde iş tatminleri ve örgütsel bağlılık düzeyleri artan çalışanların görev ve bağlamsal performansları da artmaktadır. Son olarak çalışanların görev ve bağlamsal performans göstermelerinde sadece kişisel de ğerlerinin örgütleriyle uyuşması değil, aynı zamanda onların işlerine yönelik tutumlarının da önemli rol oynadığı bulgusuna ulaşılmaktadır.

Ek olarak literatürde kişi-örgüt uyumu ile performans arasındaki ilişkide iş tutumlarının aracı rollerinin olup olmadığını inceleyen çalışmalarda farklı sonuçlar elde edilmiştir. Örneğin Arthur vd. (2006)'nin yaptıkları meta analizi ile kişi-örgüt uyumu ile performans arasındaki ilişkide iş tutumlarının aracı rollerinin olduğuna dair bulgulara ulaşılmıştır. Benzer şekilde Öcel (2013) kişi-örgüt uyumu ile bağlamsal performans arasındaki ilişkide örgütsel bağlılık alt boyutlarının aracı rolünü incelemiş ve normatif bağlılık ve duygusal bağ lılığın kişi-örgüt uyumu ile bağlamsal performans arasındaki ilişkide aracı rol oynadığı ancak devamlılık bağlılığının ise böyle bir aracı rolünün olmadığı bulgusuna ulaşmıştır. Diğer taraftan McCulloch \& Turban (2007) iş tatmininin kişi-örgüt uyumu ve performans arasındaki ilişkideki aracı rollerini incelemişler ve kişi-örgüt uyumu ile iş tatmininin ilişkili olduğu bulgusuna ulaşmalarına rağmen, hem kişi-örgüt uyumu hem de iş tatmini ile performans arasında herhangi bir anlamlı ilişki elde edilemediği için iş tatminin aracı rol oynadığı ile ilgili herhangi bir bulguyu ulaşamamışlardır.

$\mathrm{Bu}$ çalışmada ise iş tatmini kişi-örgüt uyumu ile bağlamsal performans arasındaki ilişkide tam ara değişken etkisine, kişi-örgüt uyumu ile görev performansı arasındaki ilişkide ise kısmi ara değişken etkisine sahip olduğu bulgusuna ulaşılmıştır. Benzer şekilde örgütsel bağlılığın kişi-örgüt uyumu ile görev performansı arasındaki ilişkide tam ara değişken etkisine, kişi-örgüt uyumu ile bağlamsal performans arasındaki ilişkide ise kısmi ara değişken etkisine sahip olduğu bulgusuna ulaşılmıştır.

\section{Sonuç}

Kurumlar rakipleri ile rekabet ederken kendileri için en gerekli unsurlardan biri olan insan faktörüne değer vermeleri gerekmektedir. İnsan faktörüne gerekli değerin verildiğinin göstergelerinden birisi kişi-örgüt uyumunun sağlanmasıdır. Kurumunun sahip olduğu amaç ve hedefleri ile aynı amaç ve hedefleri paylaşan yani çalıştığ 1 kurumuyla uyum içinde olan bireyler işten ayrılma niyeti içerisine girmeyerek belirlenen hedeflerin yerine getirilmesinde süreklilik göstererek, kurumuna yeterli faydayı sağlayacaklardır. Bu bağlamda yöneticiler çalışanın iş ile, takımı ile veya yöneticisi ile kurduğu bağlarda daha çok dikkat etmeli ve herhangi birinden doğan uyumsuzluğu diğeri ile dengelemeye çalışmalıdır. Kurumunun değerleri ve kimliği ile uyumlu bir çalışan kurumundan ayrılmak istemeyecektir. Kişi-örgüt uyumunun sağlanmasından firmaların insan kaynakları yönetimine de görevler düşmektedir. İlk olarak işe alımlarda 
kurumların değerleri ve adayların kişilik özelliklerinin uyumlu olmasına dikkat edilmelidir. Örneğin, adayın daha önceden sahip olduğu iş deneyimi mülakatı yapan değerlendiriciye, adayın kişi-örgüt uyumu hakkında bilgi verebilir.

Çalışanların beklenen düzeyde performansa sahip olmalarını sağlamak için yöneticiler tarafından yapılması gerekilen en önemli faaliyetlerden biri çalışanların yaptıkları işten keyif almalarını sağlayacak ortam ve koşulları oluşturmaktır. Çalışan huzurlu bir çalışma ortamına sahip olduğunda sadece görev performansı kapsamındaki faaliyetleri değil, aynı zamanda, kendisinden beklenenin ve iş tanımında yazılanın ötesinde, örgütün fiziksel, psikolojik ve sosyal ortamına katkı sağlayacak ve bağlamsal performans kapsamındaki faaliyetleri de gönüllü olarak yerine getirmek isteyecektir. Ek olarak, çalışanların kuruma karşı bağlılığını arttıran farklı teşvikler bulunmaktadır. Örneğin, bazı çalışanlar finansal ödüller ile motive olurken, bazıları ise kariyer odaklı teşviklerle motive olmaktadır. Bu bağlamda, yöneticilerin iyi bir gözlemci olarak çalışana uygun teşvikleri bulup, daha fazla motive olmasını sağlayarak kuruma bağlılıklarını arttırmaya çalışmalıdır. Çalışanların problemlerini rahatça ifade edebildiği bir ortam sağlanırsa bu durumda çalışanlar kendilerini duygusal olarak daha güçlü hissedecek ve kurumlarına bağlılıkları artacaktır. Bu doğrultuda, yöneticilerin gerekli iletişim eğitimleri alarak çalışanlarıyla doğru iletişim kurmaları sağlanarak örgütsel bağlılığın arttırılması sağlanabilir.

Son olarak bu konuda araştırma yapmak isteyen diğer araştırmacılara da bazı öneriler sunulabilir. İlk olarak, özellikle çalışmanın uygulanabilirliğini kolaylaştırmak amacıyla kavramsal modelde yer alan bütün yapılar genel düzeyde ölçülmüşler ve bu yapıların alt boyutları dikkate alınmamıştır. Gelecek araştırmalarda kavramları alt boyutlarıyla incelenebilir. İkinci olarak bu çalışmada, özellikle işyerinde, nasıl davrandığımız üzerinde en fazla etki potansiyeline sahip olan ve çalışma ortamı içerisinde en çok incelenen ve tartışılan tutumlardan ikisi olan iş tatmini ve örgütsel bağlılık dikkate alınmıştır. İşe sarılma, örgütsel destek algısı ve çalışanın işe angaje olması (tutulması) gibi diğer iş tutumlarının kişi-örgüt uyumu ile performans arasındaki ilişkide ara değişken etkileri sonraki çalışmalarda incelenebilir. Üçüncü olarak gelecekteki araştırmalar, daha geniş bir örneklem ile veya belirli bir sektör çerçevesinde tekrarlanabilirler. Hizmet, ticaret, sınai veya yüksek teknoloji üretiminin olduğu sektörlerde ya da farklı bölgelerde bulunan firmalar arasında karşılaştırmalar yapılabilir.

\section{Kaynakça}

Adıgüzel, O., \& Kayadibi, K. (2015). Kişi-Örgüt uyumu sürecinde entelektüel sermayenin iş doyumu ve örgütsel çekicilik üzerine etkisi: Bir üniversite hastanesi örneği. İşletme Araştırmaları Dergisi, 7(4), 92-122.

Akbaş, T. T. (2010). Örgütsel etik iklim, kişi-örgüt uyumu, örgütsel bağlılık ve örgütsel vatandaşlık davranışı ilişkisi: Görgül bir araştırma (Yayınlanmamış Doktora Tezi). Gazi Üniversitesi, Sosyal Bilimler Enstitüsü.

Arthur Jr, W., Bell, S. T., Villado, A. J., \& Doverspike, D. (2006). The use of person-organization fit in employment decision making: An assessment of its criterion-related validity. Journal of Applied Psychology, 91(4), 786-801.

Ayar, H. (2016). Dinamik örgütsel kuralların firmanın pazarlama yeteneği üzerine etkileri (Yayınlanmamış Doktora Tezi). Gebze Teknik Üniversitesi, Sosyal Bilimler Enstitüsü.

Babin, B. J., \& Boles, J. S. (1998). Employee behavior in a service environment: A model and test of potential differences between men and women. Journal of Marketing, 62(2), 77-91. 
Baron, R. M., \& Kenny, D. A. (1986). The moderator-mediator variable distinction in social psychological research: Conceptual, strategic, and statistical considerations. Journal of Personality and Social Psychology, 51(6), 1173.

Bayram, L. (2005). Yönetimde yeni bir paradigma: Örgütsel bağlllık. Sayıştay Dergisi, 59(59), 125-139.

Bolat, O. İ., \& Bolat, T. (2008). Otel işletmelerinde örgütsel bağlılık ve örgütsel vatandaşlık davranışı ilişkisi. Balıkesir Üniversitesi Sosyal Bilimler Enstitüsü Dergisi, 11(19), 75-94.

Borman, W. C., \& Motowidlo, S. J. (1997). Task performance and contextual performance: The meaning for personnel selection research. Human Performance, 10(2), 99-109.

Borman, W. C., \& Motowidlo, S. M. (1993). Expanding the criterion domain to include elements of contextual performance. In N. Schmitt, W. C. Borman (Eds.), Personnel selection in organizations. San Francisco: USA.

Borman, W.C., Hanson, M. A., \& Hedge, J. W. (1997). Personnel selection. Annual Review of Psychology, 48(1), 299-337.

Budak, A. (2006). Kamu sektöründe çalışanların iş tatmin düzeyleri: Milli Savunma Bakanlığı akaryakıt ikmal ve NATO Pol Tesisleri'nde bir uygulama (Yayınlanmamış Yüksek Lisans Tezi). Anadolu Üniversitesi, Sosyal Bilimler Enstitüsü.

Cable, D. M., \& DeRue, D. S. (2002). The convergent and discriminant validity of subjective fit perceptions. Journal of Applied Psychology, 87, 875-884.

Carpenter, M., Bauer, T., \& Erdogan, B. (2010). Principles of management. Jupiterimages Corporation, USA.

Chatman, J. A. (1989). Improving interactional organizational research: A model of person-organization fit. Academy of Management Review, 14(3), 333-349.

Chatman, J. A. (1991). Matching people and organizations: Selection and socialization in public accounting firms. Administrative Science Quarterly, 36, 459-484.

Dormann, C., \& Zapf, D. (2001). Job satisfaction: A meta-analysis of stabilities. Journal of Organizational Behavior, 22(5), 483-504.

Edwards, B. D., Bell, S. T., Arthur, Jr, W., \& Decuir, A. D. (2008). Relationships between facets of job satisfaction and task and contextual performance. Journal of Applied Psychology, 57(3), 441-465.

Elden, B. (2017). Psikolojik sözleşme ihlali ile işten ayrılma niyeti ilişkisinde birey-örgüt uyumunun düzenleyici rolü (Yayınlanmamış Yüksek Lisans Tezi). Nevşehir Hacı Bektaş Veli Üniversitesi, Sosyal Bilimler Enstitüsü.

Farooqui, M. S., \& Nagendra, A. (2014). The impact of person organization fit on job satisfaction and performance of the employees. Procedia Economics and Finance, 11, 122-129.

Fornell C., \& Larcker D. F. (1981). Evaluating structural equation models with unobservable variables and measurement error. Journal of Marketing Research, 18(1), 39-51.

Goodman, S. A., \& Svyantek, D. J. (1999). Person-Organization fit and contextual performance: Do shared values matter. Journal of Vocational Behavior, 55(2), 254-275.

Hair J. F., Black W. C., Babin B. J., \& Anderson, R. E. (2009). Multivariate data analysis, 7th Edition, Englewood Cliffs, NJ: Prentice-Hall.

Hartline, M., \& Ferrell, O. C. (1996). The management of customer-contact service employees: An empirical investigation. Journal of Marketing, 60, 52-71.

Hill, C. W. L., \& McShane, S. L. (2008). Principles of management. New York, USA: McGraw-Hill/ Irwin. 
Jawahar, I. M., \& Carr, D. (2007). Conscientiousness and contextual performance: The compensatory effects of perceived organizational support and leader-member exchange. Journal of Managerial Psychology, 22(4), 330-349.

Kalkavan, S., \& Katrinli, A. (2014). The effects of managerial coaching behaviors on the employees' perception of job satisfaction, organisational commitment and job performance: Case study on insurance industry in Turkey. Procedia-Social and Behavioral Sciences, 150, 1137-1147.

Kök, S. B. (2006). İş tatmini ve örgütsel bağlllı̆̆ın incelenmesine yönelik bir araştırma. Atatürk Üniversitesi İktisadi ve İdari Bilimler Dergisi, 20(1), 291-317.

Kristof,A.L. (1996). Person-organization fit: An integrative review of its conceptualizations, measurement and implications. Personnel Psychology, 49(1), 1-49.

Mcculloch, M. C., \& Turban, D. B. (2007). Using person-organization fit to select employees for highturnover jobs. International Journal of Selection and Assessment, 15(1), 63-71.

Moripek, İ. (2016). Kişi-Örgüt uyumu ile örgütsel bağlılık arasındaki ilişkinin incelenmesi: Havacılık sektörü örneği (Yayınlanmamış Yüksek Lisans Tezi). Beykent Üniversitesi, Sosyal Bilimler Enstitüsü.

Netemeyer, R. G., Bowles, J. S., MacKee, D. O., \& McMurrian, R. (1997). An investigation into the antecedents of organizational citizenship behaviors in a personal selling context. Journal of Marketing, 61, 85-98

Ostroff, C. (1992). The relationship between satisfaction, attitudes and performance: An organizational level analysis. Journal of Applied Psychology, 77(6), 963-974.

Öcel, H. (2013). Örgüt kimliğinin gücü, algılanan örgütsel prestij ve kişi-örgüt uyumu ile bağlamsal performans arasındaki ilişkiler: Örgütsel bağlılı̆̆ın aracı rolü. Türk Psikoloji Dergisi, 28(71), 37 53.

Peng, Y. P. (2014). Job satisfaction and job performance of university librarians: A disaggregated examination. Library \& Information Science Research, 36(1), 74-82.

Randall, D. M. (1987). Commitment and the organization: The organization man revisited. Academy of Management Review, 12(3), 460-471.

Robbins, S. P., \& Judge, T. A. (2013). Örgütsel davranış. 14. basımdan çeviri, (Çev. İ. Erdem), Ankara: Nobel Yayıncilık.

Schneider, B. (1987). The people make the place. Personnel Psychology, 40, 437-454.

Schwepker Jr. C. H. (2001). Ethical climate's relationship to job satisfaction, organizational commitment and turnover in the sales force. Journal of Business Research, 54(1), 39-52.

Toklu,A.T. (2016). Çalışanlarda iş sağlığı ve güvenliği uygulamalarının örgütsel bağlılık, işe yabancılaşma ve iş performansına olan etkisinin incelenmesi (Yayınlanmamış Doktora Tezi). Gebze Teknik Üniversitesi, Sosyal Bilimler Enstitüsü.

Vancouver, J. B., \& Schmitt, N. W. (1991). An exploratory examination of person-organization fit: Organizational goal congruence. Personnel Psychology, 44(2), 333-352.

Verquer, M. L., Beehr, T. A., \& Wagner, S. H. (2003). A meta-analysis of relations between personorganization fit and work attitudes. Journal of Vocational Behavior, 63(3), 473-489.

Williams, L. J., \& Anderson, S. E. (1991). Job satisfaction and organizational commitment as predictors of organizational citizenship and in-role behaviors. Journal of Management, 17(3), 601-617. 